\title{
Demonstration of Ubiquitin Following Ischemia and Reperfusion of Spinal Cord Neurons in the Rabbit
}

\author{
M. FERIKOVÁ, E. MECHÍROVÁ, I. DOMORÁKOVÁ
}

Department of Histology and Embryology, Faculty of Medicine, P. J. Šafárik University, Košice, Slovak Republic

\author{
Received October 9, 2003 \\ Accepted February 11, 2004
}

\section{Abstract}

Feriková M., E. Mechírová, I. Domoráková: Demonstration of Ubiquitin Following Ischemia and Reperfusion of Spinal Cord Neurons in the Rabbit. Acta Vet. Brno 2004, 73: 51-54.

The ubiquitin proteolytic system plays an important role in a broad array of basic cellular processes. One of them is breakdown of proteins that may occur in nerve cells after ischemia/reperfusion. Using ubiquitin immunohistochemistry we evaluated the presence of ubiquitin-like immunoreactive material in rabbit spinal cord following 30 minutes of ischemia and 24 hours of reperfusion. In the $\mathrm{L}_{5}, \mathrm{~L}_{6}$ spinal cord segments, the motor neurons in lamina IX of ventral horns and the interneurons of intermediate zone showed higher immunoreactivity to ubiquitin as in the control sections. The cytoplasm of affected nerve cells contained numerous intensively ubiquitin-positive granules. In addition, the ubiquitin-positive material was present in the nerve cell nuclei as well. Clinically, the ischemia and reperfusion caused damage and resulted in paraplegia of the hind limbs. The results suggest that the increase of ubiquitinpositive material in affected nerve cells is necessary for non-lysosomal degradation of altered proteins occurring during ischemia/reperfusion. Incrased rate of ubiquitin synthesis is necessary for survival of damaged cells.

Ubiquitin, nonlysosomal proteolytic system, ischemia, reperfusion, rabbit, spinal cord

Many studies have demonstrated the function of ubiquitin in the proteolytic system of the cells (Ciechanover et al. 1984; Parag et al. 1987; Attaix et al. 2002). The discovery of the ubiquitin pathway and its many substrates and functions has revolutionized the concept of intracellular protein degradation. Ubiquitin proteolytic system plays an important role in a broad array of cellular processes, above all in regulation of cell cycle, differentiation and development, modulation of cell surface receptors and ion channels, and DNA repair (Ciechanover 1998; Urbanowski and Piper 2001). Ubiquitin is a low molecular weight stress protein found in all eukaryotic cells. It labels altered proteins that the cells produce after various forms of injury. The number of cellular proteins targeted by ubiquitin is growing rapidly (Ciechanover et al. 2000). Degradation of an altered protein via the nonlysosomal ubiquitin proteolytic system consists of conjugation of ubiquitin to the substrate and proceeds via three enzymes $-\mathrm{E}_{1}$, $\mathrm{E}_{2}$, and $\mathrm{E}_{3}$ (Fig. 1) Ubiquitinated proteins are degraded by $26 \mathrm{~S}$ proteasome to short peptides (Attaix et al. 2002) with the release of free and reutilizable ubiquitin (Hers h ko and Ciechanover 1998). The aim of the present study was to compare the staining pattern of ubiquitin in the spinal cord neurons after $30 \mathrm{~min}$ of ischemia and $24 \mathrm{~h}$ of reperfusion with control sections in rabbit.

\section{Materials and Methods}

The experiments were carried out on 6 Rex-blue male rabbits, clinically healthy, weighing 2.5-3.0 kg, 6-12month-old (University of Veterinary Medicine in Košice). The experimental animals were housed in individual cages and fed standard laboratory chow ad libitum. The rabbits were kept at a temperature of $20-21^{\circ} \mathrm{C}$ and exposed

Address for correspondence:

Mgr. Marianna Feriková

Department of Histology and Embryolog

Faculty of Medicine, P.J.Safarik University
Phone: +421556222606

Fax: +421 556428141

E-mail: ferikom@yahoo.co.uk 


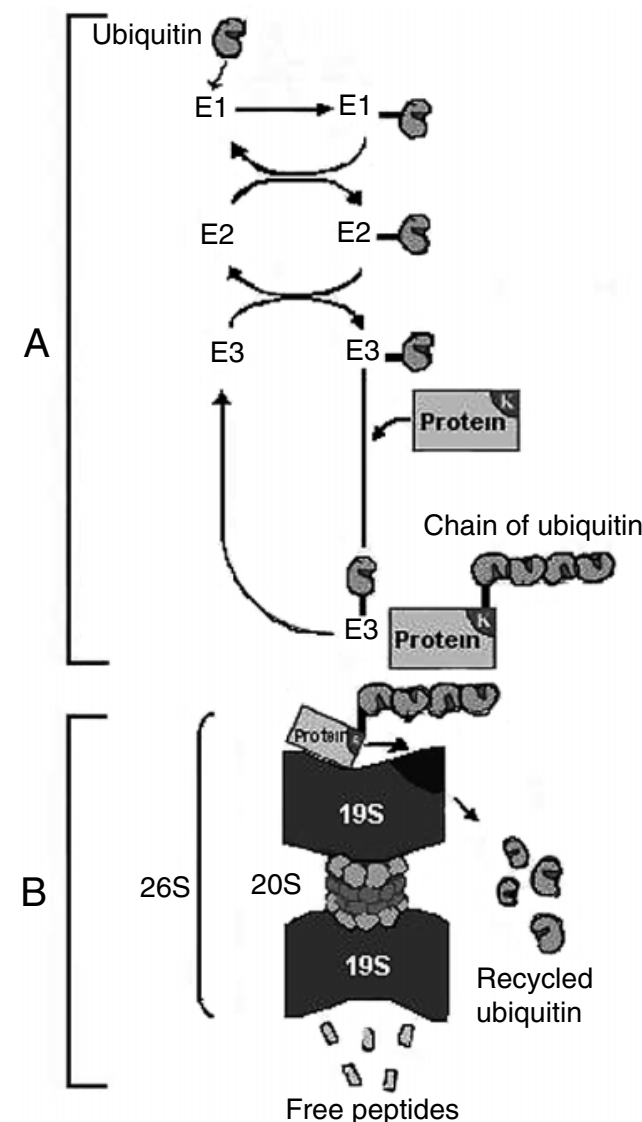

Fig. 1. A: Conjugation of ubiquitin to the labeled substrate.

B: Degradation of altered proteins by $26 \mathrm{~S}$ proteasome complex.

(Oxiginal drawing based on Ciechanover et al. 2000; Attaix et al. 2002.)

Fig. 1. A schematic drawing of ubiquitin proteolytic pathway.

to alternate light and dark periods of $12 \mathrm{~h}$. For mapping of ubiquitin-positive neurons in the spinal cord of the rabbit there were two groups of animals:

1. control group - $(\mathrm{n}=3)$

2. experimental group $-30 \mathrm{~min}$ of ischemia/24 h of reperfusion $(\mathrm{n}=3)$.

The animals were anesthetized with thiopental $(40 \mathrm{mg} / \mathrm{kg}$, i. v.) and $30 \mathrm{~min}$ of ischemia was induced by occlusion of aorta below the left renal artery. After release of occlusion the animals survived $24 \mathrm{~h}$ and following deep anesthesia with thiopental were transcardially perfused with $1000 \mathrm{ml} 0.9 \%$ saline and $1000 \mathrm{ml} 4 \%$ paraformaldehyde in $0.1 \mathrm{M}$ phosphate buffered saline ( $\mathrm{pH}$ 7.4). Handling of experimental animals was approved by the Ethical Committee of Medical Faculty of P. J. Safárik University in Košice.

Removed spinal cords were postfixed for $2 \mathrm{~h}$ in $4 \%$ paraformaldehyde. The $\mathrm{L}_{5}-\mathrm{L}_{6}$ segments of the spinal cord were dissected and stored in sucrose $(15 \%)$ for $2 \mathrm{~h}$ and then in $30 \%$ sucrose overnight at $4{ }^{\circ} \mathrm{C}$. The fixed material was sectioned into $40 \mu \mathrm{m}$ thick sections in a cryostat at $-22{ }^{\circ} \mathrm{C}$. The sections were processed for immunohistochemistry. Endogenous peroxidase was blocked via $3 \% \mathrm{H}_{2} \mathrm{O}_{2} / 0.2 \%$ Triton X-100 in methanol (30 $\mathrm{min}$ ). After a $2 \mathrm{~h}$ incubation in 5\% normal goat serum in $0.1 \mathrm{M}$ phosphate buffered saline (PBS) with $1 \%$ bovine serum albumin the sections were preincubated in primary rabbit polyclonal antibody to ubiquitin (Sigma; 1:100, $\mathrm{U}$ 5379) overnight at $4^{\circ} \mathrm{C}$. Sections were incubated in anti-rabbit biotinylated secondary antibody (Sigma; 1:20) for $2 \mathrm{~h}$ and next with extravidin-peroxidase (Sigma; $1: 20$ ) for $1 \mathrm{~h}$. The sections were washed in $0.1 \mathrm{M}$ phosphate buffered saline, and 3,3'- diaminobenzidine tetrahydrochloride (Fluka) was used as detection system for visualization of ubiquitin antibody peroxidase. Prior to counterstaining by Mayer hematoxylin the sections were washed with distilled water; dehydrated in alcohol, cleared in karbolxylene and xylene. Finally the sections were mounted in Entellan (Merck). For examination we used OLYMPUS light microscope and the pictures were saved via the program OLYMPUS DP-SOFT. 


\section{Results}

The effects of transient spinal cord ischemia/reperfusion on ubiquitin antibody immunohistochemical reaction in the rabbit were investigated and the appearance of ubiquitin - positive neurons was evaluated in the control and experimental group of animals.

In the control sections a lightly diffuse immunoreactivity for ubiquitin was observed in the cytoplasm of neurons throughout the gray matter of the lumbar spinal cord. The nuclei of larger neurons in the ventral horn and intermediate zone were lightly ubiquitin-positive as well (Plate VIII, Figs 2, 3). In contrast, the results from the experimental group of rabbits demonstrated two important differences - in distribution and in intensity of ubiquitin positivity. The ubiquitin positive neurons were irregularly arranged in the gray matter. Predominantly in the lamina IX of the ventral horn (Plate IX, Fig. 5) large motor neurons showed intensive ubiquitin positivity in the cytoplasm and nuclei and in the intermediate zone where the interneurons contain darkbrown ubiquitin positive granules (Plate IX, Fig. 4). In the dorsal horns the perikarya of nerve cells were randomly labeled with ubiquitin but in comparison with the control sections the number of ubiquitin labeled nerve cells is increased. Clinically, the animals showed paraplegia of hind limbs after $30 \mathrm{~min}$ of ischemia and $24 \mathrm{~h}$ of reperfusion.

\section{Discussion}

Ischemia/reperfusion damage, induced by occlusion of aorta below the left renal artery indicates that changes in ubiquitin production are in close relation with surviving of neurons in the spinal cord. Several previous studies have demonstrated by means of immunohistochemistry that neurons (Dewar et al. 1993) and other cells (Bond and Schlesinger 1985; Bond and Schlesinger 1986; Parag et al. 1987) respond to stressful stimuli by elevated production of ubiquitin, a member of the stress protein family. Interestingly, the injury to peripheral nerves induces an increased production of ubiquitin mRNA (Savedia and Kierman, 1994) and ubiquitin (Lanteri-Minet et al. 1993) in the corresponding motor neurons of the spinal cord. Morphological changes of the nerve cells after different histochemic, impregnative, Nissl or electron microscopic methods after ischemia/reperfusion were described by many authors (Brown et al. 1972; Brown 1977; Crain et al.1988; Heimer and Peters 1968; Inamura et al. 1987; Mechírová and Domoráková 2002,).

In this study many nerve cell perikarya directly exposed to $30 \mathrm{~min}$ of ischemia and $24 \mathrm{~h}$ of reperfusion showed increase of ubiquitin positivity. The most vulnerable motor neurons in lamina IX of ventral horn showed intensive ubiquitin positivity with formation of massive ubiquitin aggregates in the cytoplasm of affected cells that were clinically demonstrated by paraplegia of hind limbs. We suppose that increased ubiquitination in the nerve cells destined to survive is a protective response to ischemia/reperfusion, but massive aggregation of ubiquitinated abnormal proteins in the ischemia/reperfusion damaged neurons in the ventral horns can be the result of broken proteolytic ubiquitin pathway and leads to ischemic cell death. Taking into consideration our results with those of Hos s mann (1993) and Hu et al. (2000) we can conclude that massive protein aggregates may impair nuclear membrane function, in the Golgi complex may damage post-translational protein modification, on the mitochondrial membrane may result in overproduction of reactive oxygen species and severe secondary energy failure that initiates ischemic cell death. Finally, aggregation of ubiquitinated abnormal proteins on the neuronal cell membrane may signal microglia kill affected neurons.

\section{Dôkaz ubiquitínu po ischémii a reperfúzii v neurónoch miechy králika}

Ubiquitínový proteolytický systém hrá dôležitú úlohu vo velkom množstve základných bunkových procesov. Jedným z nich je aj degradácia poškodených proteínov $26 \mathrm{~S}$ proteázami, 
vznikajúcich v nervových bunkách po ischémii/reperfúzii. Použitím imunohistochemickej metódy na dôkaz ubiquitínu sme po 30 minútovej ischémii a 24 hodinovej reperfúzii, vyhodnotili výskyt ubiquitín - pozitívnych štruktúr v mieche králika. V segmentoch miechy $\mathrm{L}_{5}, \mathrm{~L}_{6}$, vykazovali motorické neuróny $\mathrm{v}$ lamina IX predných rohov a interneuróny $\mathrm{v}$ zona intermedia vyššiu ubiquitín - pozitivitu ako to bolo v kontrolných rezoch. Cytoplazma poškodených nervových buniek bola intenzívne ubiquitín - pozitívna. Ubiquitín - pozitívny materiál sa vyskytoval aj $\mathrm{v}$ jadrách nervových buniek. Ischémia a reperfúzia zapríčinili poškodenie, ktoré sa klinicky prejavilo paraplégiou zadných končatín. Výsledky naznačujú, že zvýšenie ubiquitín - pozitivity v ischémiou/reperfúziou poškodených neurónoch svedčí o nadmernej nelyzozomálnej degradácii alterovaných proteínov vznikajúcich počas ischémie/reperfúzie. Zvýšená syntéza ubiquitínu je nevyhnutným predpokladom pre prežívanie poškodených buniek.

\section{Acknowledgements}

This study was supported by a VEGA grant of the Slovak Ministry of Education 1/8294/01.

\section{References}

ATTAIX, D, COMBARET, L, POUCH, MN, TAILLANDIER, D 2002: Cellular control of ubiquitin-proteasomedependent proteolysis. Am Soc Anim Sci 80: E56-E63

BOND, V, SCHLESINGER, MJ 1985: Ubiquitin is a heat shock protein in chicken embryo fibroblast. Mol Cell Biol 5: $949-956$

BOND, V, SCHLESINGER, MJ 1986: The chicken ubiquitin gene contains a heat shock promoter and expresses an unstable mRNA in heat shocked cells. Mol Cell Biol 6: 4602-4610

BROWN, AW, BRIERLEY, JB 1972: Anoxic-ischemic cell change in rat brain: light microscopic and fine-structural observations. J Neurol Sci 16: 59-84

BROWN, AW 1977: Structural abnormalities in neurones. J Clin Pathol 11: 155-169

CIECHANOVER, A, FINLEY, D, VARSHAVSKY, A 1984: The ubiquitin-mediated proteolytic pathway and mechanisms of energy-dependent intracellular protein degradation. J Cell Biochem 24: 27-53

CIECHANOVER, A 1998: The ubiquitin-proteasome pathway: on protein death and cell life. Embo Member's Rev 17:7151-7160

CIECHANOVER, A, ORIAN, A, SCHWARTZ, AL 2000: Ubiquitin-mediated proteolysis: biological regulation via destruction. BioEssays 22: 442-451

CRAIN, BJ, WESTERKAM, WD, HARRISON, AH, NADLER, JV 1988: Selective neuronal death after transient forebrain ischemia in the Mongolian gerbil: a silver impregnation study. Neurosci 27: 387-402

DEWAR, D, GRAHAM, DI, TEASDALE, GM, MCCULLOCH, J 1993: Alz-50 and ubiquitin immunoreactivity is induced by permanent focal cerebral ischemia in the cat. Acta Neuropathol 86: 623-629

HEIMER, L, PETERS, A 1968: An electron microcope study of a silver stain for degenerating boutons. Brain Res 8: $337-346$

HERSHKO, A, CIECHANOVER, A 1998: The ubiquitin system. Annu Rev Biochem 67:425-479

HOSSMANN, KA 1993: Disturbances of cerebral protein synthesis and ischemic cell death. Prog Brain Res 96: 167-177

HU, BR, MARTONE, ME, JONES, YZ, LIU, CL 2000: Protein aggregation after transient cerebral ischemia. J Neurosci 20: 3191-3199

INAMURA, K, OLSSON, Y, SIESJO, BK 1987: Substantia nigra damage induced by ischemia in hyperglycemic rats. A light and electron microscope study. Acta Neuropathol 75: 131-139

LANTERI-MINET, M, DESMEULES, JA, MENETREY, D 1993: Opposite effects of axon damage on heat shock proteins (hsp 70) and ubiquitin contents in motor neurons of neuropathic rats. Neurosci Lett 153: 49-52

MECHÍROVA, E, DOMORÁKOVÁ, I 2002: NADPH-d activity in the spinal cord after ischemic injury and the effects of pretreatment with Ginkgo biloba extract (EGb 761). Acta histochem 104: 427-430

PARAG, HA, RABOY, B, KULGA, RG 1987: Effects of heat shock on protein degradation in mammalian cells: involvement of the ubiquitin system. Embo J 6: 55-61

SAVEDIA, S, KIERNAN, JA 1994: Increased production of ubiquitin mRNA in motor neurons after axotomy. Neropathol Appl Neurobiol 20: 577-586

URBANOWSKI, JL, PIPER, RC 2001: Ubiquitin sorts proteins into the intralumenal degenerative compartment of the late-endosome/vacuole. Traf c Munksgaard International Publishers 2: 622-630 
Plate VIII

Feriková M. et al.: Demonstration of Ubiquitin... pp. 51-54

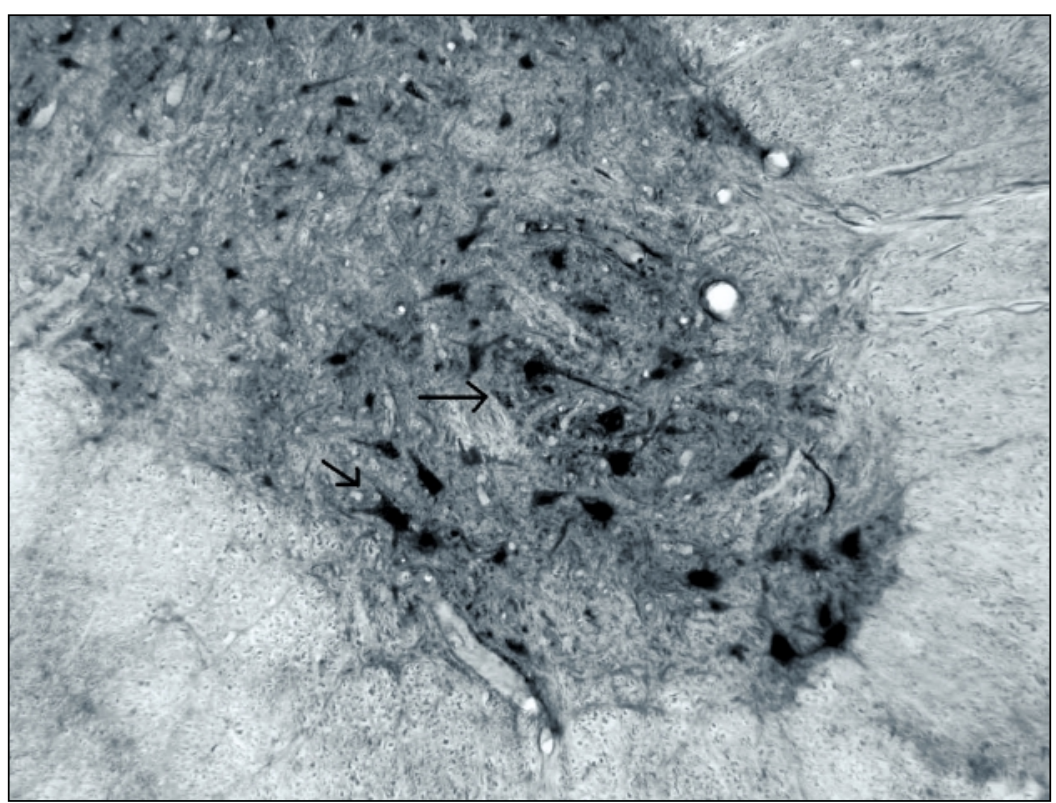

Fig. 2. Regularly arranged ubiquitin positive neurons in the ventral horn of the spinal cord $\mathrm{L}_{5}$ segment control section. $\times 100$.

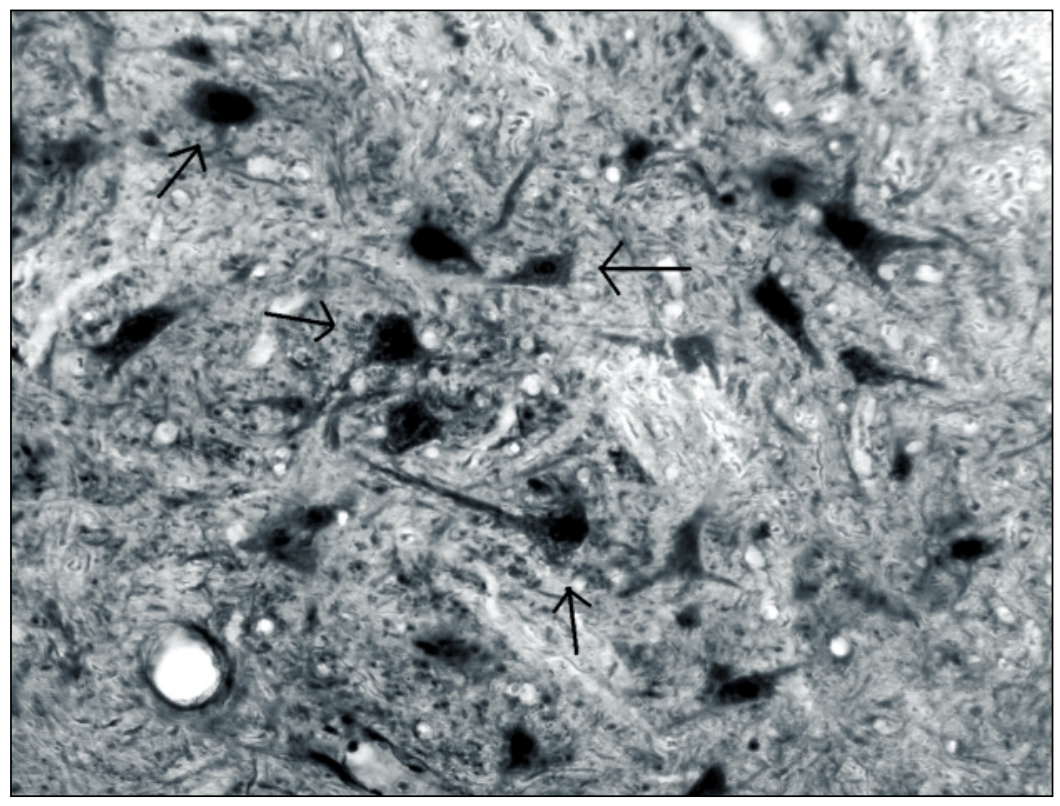

Fig. 3. Higher magnification of $40 \mu \mathrm{m}$ thick cryostat section of spinal cord from control group. In the cytoplasm of the neurons sharp-faced light brown granules of ubiquitin are seen. $\times 250$. 
Plate IX

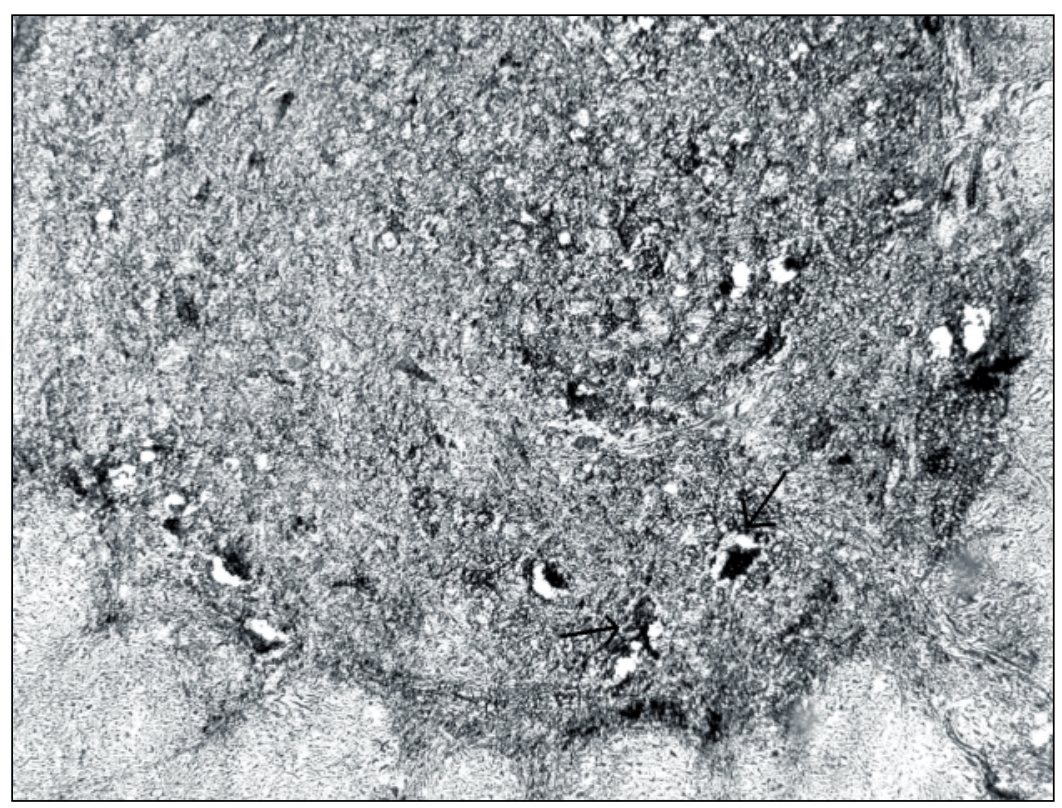

Fig. 4. After $30 \mathrm{~min}$ of ischemia and $24 \mathrm{~h}$ of reperfusion dark brown granules of ubiquitin are present in the cytoplasm of vulnerable neurons of the spinal cord ventral horn (arrows). $\times 150$.



Fig. 5. Cryostat section of the $\mathrm{L}_{5}$ spinal cord segment from the experimental group. In the lamina IX of the ventral horn damaged, dark brown, ubiquitin positive neurons are seen. In this area the first signs of necrosis are visible. $\times 400$. 